\title{
WHITMAN'S "WORD OF THE MODERN" AND THE FIRST MODERN WAR
}

\section{KATHERINE KinNeY}

In the Gettysburg Address, Abraham Lincoln accomplished what few other Americans of the day could manage; in the face of the Civil War's most terrible effects, Lincoln offered no qualification for placing the War within a providential vision of American history. Standing at Gettysburg, on the ground where, just four months before, over 50,000 men had fallen in three days of battle, Lincoln affirmed without equivocation that the blood which soaked the ground had consecrated the nation's rebirth. In The Unwritten War, Daniel Aaron describes the doubts and conflicts which plagued the leading authors of the day, preventing, as Aaron argues, anyone from producing the long hoped for national epic-the American Paradise Lost. In particular, Aaron suggests, writers like Herman Melville, Mark Twain, and Henry Adams feared that the North as well as the South had been destroyed by the war. In their writings one sees the founders' dream usurped by a mechanized mass society and ruthless capitalism. Many Northerners, Aaron suggests, in the years after the war, found themselves in increasing sympathy with the rebel figure as they became increasingly alienated from an imperial United States. ${ }^{1}$

Walt Whitman shared more fully Lincoln's vision of the war as necessary to the preservation and affirmation of the democratic union he cherished. Critics have rightfully emphasized Whitman's celebration of the war's democratic force, but have largely ignored a powerful, if often subtextual, fear and resistance voiced in the war poems and proseparenthetical, denied, hidden-but expressing the possible threats the war posed to democracy. Whitman's vision of America remains intact, but ultimately this wholeness is earned not by ignoring the war's dangers, but by giving them voice and counter-balancing them with the redemptive powers Whitman did find released by the war.

At the heart of this struggle is Whitman's concept of the "en masse." In his first edition of Leaves of Grass, Whitman proclaimed:

Endless unfolding of words of ages!

And mine a word of the modern . . . . a word en masse. ${ }^{2}$ 
The Civil War transformed Whitman's sense of both the word "en masse" and the nature of its modernity. Throughout his poetry and prose related to the war, Whitman affirms that the war justified his faith in the "en masse" - in the essential goodness and democratic spirit of the American people. For Whitman, the "[t]wo great spectacles, immortal proofs of democracy" were the general, voluntary raising and disbanding of the Union army $(S D, 1: 25) .{ }^{3}$ But these works also voice a fear that the war had brought to the center of national life forces of the "aggregate" of such power that the individual was being subsumed by them. In Drum-Taps, the closer a poem moves to a soldier's experience of war, the more emphatic the expression of such fears becomes.

The massive, mechanized, and anonymous confrontations of the armies of the North and South marked the advent of modern war. This modernity signalled a transformation in Whitman's vision of the "en masse" from the bonding of free individuals through mutual consent into "the long series of tendencies, shapings, which few are strong enough to resist, and which now seem, with steam-engine speed, to be everywhere turning out generations of humanity like uniform iron castings" $(D V, 2: 424)$. The aggregate, whose purpose in a democracy was to be the support and protection of the individual, threatened to become an inhumane leveler.

The battle lines drawn by the Civil War intensified the split between the ideas of individualism and union. Whitman believed, with John Stuart Mill, that a "grand nationality" must allow "full play for human nature to expand itself in numberless and even conflicting directions" ( $D V, 2: 362)$. But the Civil War, which finally had "lastingly condense[d] -Nationality" (2:508), also polarized the values of assertive individualism and unity into the destructive extremes of fractricidal treason and mass, militaristic conformity. The South's rebellion was suppressed, but the Union victory threatened to institutionalize the right of a centralized federal power to assert its prerogative by force. Whitman knew the value of rebellious "reformers and revolutionists ... to counterbalance the inertness and fossilism . . . of human institutions" $(D V, 2: 383)$. But the defeat of the South threatened to suppress the role of rebellion, defiance and conflict in American political life. In Democratic Vistas, Whitman envisioned the geographic and ideological unity of the United States as a "composite" in which the rising West would draw intellect and justice from the North and from "the south the living soul, the animus of good and bad, haughtily admitting no demonstration but its own" (2:385). This Southern "animus" echoes Whitman's definition of that necessary "counterbalance" to democracy, "personalism": "the pride and centripetal isolation of a human being in himself" (2:391). 
In Drum-Taps, Whitman struggles with and against the forces which were shaping America through war. Aware that he could "do nothing better than accept, make the best of, and even welcome" those modern forces of conformity working at "steam-engine speed" ( $D V$, $2: 424$ ), Whitman celebrates the spectacle of the massive armies with a critical eye for the dehumanizing effects of modernity on the march. In Drum-Taps, the image of the army changes from one in which individual will and identity are merged in dedication to a common ideal to a nightmarish sequence of actions beyond the individual's understanding or control. In Specimen Days, Whitman wrote that "an inkling of this war" could come only through an appreciation of the black embers, worse than those of burnt farms, which devoured the human heart (1:81). In Drum-Taps as well, the war is not primarily the battle between North and South, but an internal one fought between democratic and anti-democratic tendencies within the individual.

The counterbalance within Drum-Taps to the dehumanizing forces of war are figures born of the war which privilege personal acts of love and sacrifice: the wound-dresser and the lover/comrade. The wounddresser affirms the integrity of the individual, not by rebelling against the forces which maim and destroy, but by facing without blinking the destruction wrought. More radical, however, is the stand of the lover/ comrade whose affirmation of homosexual love and bonding, existing outside traditional structures, challenges "all the settled laws," 4 and thus reinscribes the bond between individuals which forms the basis of democracy. In Drum-Taps, Whitman ultimately demonstrates that only love, not law, not force of arms, not mass action, can unite.

Both the original edition of Drum-Taps and that included in Leaves of Grass begin with a rousing celebration of the general and democratic response to the call of the drums. Originally the title piece of Drum-Taps and later renamed "First O Songs for a Prelude," the volume's opening poem begins with the poet, Whitman's characteristic "I," recording the change in his beloved Manhattan when the song of fife and drum replaces the "sweet opera-music" of peace (280). Mechanic and lawyer, old and young, man and woman are shown putting aside their personal business to answer the drums' call by "common consent" (281). Only the figure of the mother does not share in this "unpent enthusiasm." Her alienation from the general celebration is the single sign of resistance to the drums and is only suggested within the poem parenthetically, as if to isolate the private reaction even further from the public events: "(Loth is the mother to part,-yet not a word does she speak to detain him,)" (281). The imperative of the surrounding action silences her objection to the son marching off to war. The suppression of personal desires is figured as a noble act of self-sacrifice, but the poet poignantly notes the pain involved. 
In "Beat! Beat! Drums!" the drums' power to over-ride such personal expressions of doubt and regret is brought more clearly into focus. No longer musical, the drum-taps do not call to individuals but "burst like a force of ruthless men" through the walls of private life: of church, school, and bedroom. Unlike those of "First O Songs for a Prelude," these drums do not elicit the free and spontaneous participation of citizens, but forcibly interrupt the rhythms and actions of daily life in terms of negation and violence.

Are beds prepared for the sleepers at night in the houses? no sleepers must sleep in those beds,

No bargainers' bargains by day-no brokers or speculators - would they continue?

Would the talkers be talking? would the singer attempt to sing? (283)

The speaker is no longer the emotionally engaged Whitmanian "I" but the authoritarian voice of historical events. The rhetorical questions of the second stanza allow for no alternative to participation in the events announced by the drum.

The final stanza exhorts the drums to ignore those voices which would dissent from their "terrible" imperative:

Beat! beat! drums!-blow! bugles! blow!

Make no parley-stop for no expostulation, Mind not the timid-mind not the weeper or prayer,

Mind not the old man beseeching the young man,

Let not the child's voice be heard, nor the mother's entreaties. . . . (284)

These are not the voices of cowardice or compromise, but the loving voices of mother and child and elder, of peace and understanding. Whitman's celebration of the drum's egalitarian appeal is coupled with an acknowledgement of their fundamentally anti-democratic power. The maternal bond of love, so basic to Whitman's conception of democracy and society, is rendered silent and marginal by the war, unable to oppose the forceful subsuming of individual lives.

In "Come Up from the Fields Father," Whitman turns his full attention to the mother's experience of war, exploring the depth of her alienation and the tensions it suggests. Set on an Ohio farm in harvest season, the poet evokes the material abundance of America in its best, most natural sense. The reader is invited to smell the grapes and the buckwheat, to participate in the sensual richness of the place. But the visions of ripeness and wealth fade for the poet as the mother reads the letter which, although it promises that her wounded son will recover, she knows means his death: 
Ah now the single figure to me,

Amid all teeming and wealthy Ohio with all its cities and farms,

Sickly white in the face and dull in the head, very faint,

By the jamb of a door leans. (303)

The poet confirms the mother's intuitive knowledge that her son is already dead.

No mention is made of the cause in which he died, nor of heroic deeds or necessity. The poet centers only on the mother's withdrawal into silent grief and death. She never cries out against the powers which took "the only son" from her, but passively rebels against the life which they rule by her "one deep longing," to follow her son into death (303). Isolated as she is, the mother is no threat to the powerful call of the drums, but her alienation signifies the depth of the rupture the war bred in American society. The "meals left untouched" in the poem's final stanza represent a spiritual denial of the autumnal abundance with which the poem opens. The loss of the mother and "the only son," the rightful heir, suggests that the continuity of American life has been irrevocably broken.

This subtextual resistance to the ideals and activities of the war becomes more central in the poems which directly concern the soldiers who fought it. In the ordering of the Drum-Taps poems for inclusion in Leaves of Grass, "Come Up From the Fields Father" marks a turn in the collection to poems concerned with the terrible effects of the war on individuals. In poems such as "A March in the Ranks Hard-Prest, and the Road Unknown" and "The Artilleryman's Vision," Whitman's recognition of the anti-democratic forces unleashed by the war overwhelms his faith in the response of the "en-masse" to the Union's crisis. These two poems exemplify different but equally devastating ways in which the experience of the war undermines a man's sense of individualism and humanity. For the speaker of each poem, volition gives way to the momentum of military action, and the ability to distinguish individual human beings among the fighting troops or crowds of wounded is almost completely lost.

"A March in the Ranks Hard-Prest, and the Road Unknown" is the grimmest poem in the collection. A nightmarish vision of the individual swept along by events he cannot comprehend, the poem is Whitman's most uncompromising study of the dehumanization of the soldier by war. The poem unfolds in one long sentence, each line pushed on toward a closure which never comes; the poem ends where it begins, on "The unknown road still marching." The speaker is a member of the "sullen remnant" of a defeated troop on the march in darkness without knowledge of where they are or where they are going; the march seems simply to have a momentum all its own. The troop comes upon a makeshift hospital in a clearing which presents "a sight 
beyond all the pictures and poems ever made" (305). With no available frame of reference, the speaker's sense of disorientation is intensified as he tries to comprehend the images surrounding him. Lit by torches, the place is a Dantesque vision of smoke, flame, confusion, and indistinct, suffering bodies. The wounded lie everywhere.

The speaker looks about, trying to "absorb," to make sense of the scene, but it remains a disjointed collection of image, smell, and sound:

Faces, varieties, postures beyond description, most in obscurity, some of them dead, Surgeons operating, attendants holding lights, the smell of ether, the odor of blood, The crowd, $\mathrm{O}$ the crowd of bloody forms, the yard outside also fill'd, Some on the bare ground, some on planks or stretchers, some in the death-spasm sweating,

An occasional scream or cry, the doctor's shouted orders or calls,

The glisten of the little steel instruments catching the glint of the torches . . . .

His perceptions remain "vague" and "obscure." There is no sense of cause and effect, of relationship between the images he is trying to absorb. In Specimen Days, Whitman looks upon the camps of the wounded and asks, " - is this indeed humanity? - these butchers' shambles?" ( $S D, 1: 46)$. The speaker of the poem, weary and lost, does not even suggest that the scene before him might be a human one. He sees only "crowds" or "forms." His powers of perception, on which depend his ability to feel and sympathize, are so diminished by disorientation and fatigue that he cannot recognize humanity in such a vast, horrific state.

The only sight which appears "distinctly" to him is that of a severely wounded young soldier at his feet. The speaker bends down and attempts to "stanch the blood temporarily" (305). The act cannot save the wounded boy, but that is not its purpose. The struggle within the poem is for the speaker to salvage his own sense of humanity by connecting, if only for a moment, to another individual life, thereby asserting his own individuality. For a moment, the speaker takes control over his actions as he resists the orders to "fall in" and rejoin the march.

Then hear outside the orders given, Fall in, my men, fall in;

But first I bend to the dying lad, his eyes open, a half-smile gives he me,

Then the eyes close, calmly close, and I speed forth to the darkness,

Resuming, marching, ever in darkness marching, on in the ranks,

The unknown road still marching. (306)

The connection between the two soldiers is unvoiced and undefined, consisting of only a "half-smile." But as a sign of welcome recognition of the speaker's presence, it is unmistakably a momentary attempt, on 
each side, to embrace life before dying. The speaker's return to the march, to the blind oppressiveness of enforced routine, is a figurative death which offers none of the release associated with the boy's death. His resistance to the forces carrying him along cannot be total; Whitman cannot advocate desertion. But only the will to resist the relentless momentum of the war can preserve the soldier's sense of self and humanity.

"The Artilleryman's Vision" carries this internal war home as, years later, a veteran of the war lies in bed next to his sleeping wife and dreams of battle. Unlike the speaker of "A March in Ranks HardPrest," in his dream the artilleryman is not alienated from his experience or disoriented by the activity surrounding him. The speaker emphasizes the skill with which the gunners perform their tasks amid the confusion and activity of the battlefield.

All the scenes at the batteries rise in detail before me again, The crashing and smoking, the pride of the men in their pieces,

The chief-gunner ranges and sights his piece and selects a fuse of the right time, After firing I see him lean aside and look eagerly off to note the effect . . . (317)

The artilleryman asserts a unity of cause and effect, of men and machines. Here is the fulfillment of the call in "First $O$ Songs for a Prelude," for men able "to serve well the guns." The sounds of the guns call like the beat of the drums in earlier poems. The veteran's entrance into his "fantasy unreal" is marked by the "short $t-h-t$ ! $t-h-t$ ! of the rifle balls" and the "great shells shrieking." The sound of the cannon rouses "even in dreams a devilish exultation and all the old mad joy in the depths of my soul" (318), suggesting the "black, worse embers" Whitman claimed had been burned into the human heart by war's "lurid passions" $(S D, 1: 81)$. The artilleryman's connection to the battle is not forged by discipline, uniform, or duty, but burns within his own soul. The guns of battle raise the "devilish exultation," not of mythic Satanic rebellion, but of the giving over of one's self to a power greater than that of the individual.

Although engaged rather than alienated, the artilleryman's internalization of the war is as dehumanizing as that of the "hard-prest" soldier. $\mathrm{He}$, too, sees forms not men; "I see the gaps cut by the enemy's volleys, (quickly fill'd up, no delay,)" (317). His professional attention to shot and target cannot or will not perceive the effect of his skills in the death and mutilation of individual men. Whitman raises this subtextual tension to the surface in a parenthetical assertion of that which the vision refuses to encompass: "(The falling, dying, I heed not, the wounded dripping and red I heed not, some to the rear are hobbling,)" (318). Here is the inglorious result of such skill. The artilleryman's suppression of these bloody images allows him to revel in his own oneness with 
events without having to assume responsibility for their cost. Whitman draws our attention to this act of repression and thus to the veteran's romanticizing of his experience. We must heed the brief but graphic images of the guns' destruction, "the wounded dripping and red," even if the veteran will not.

If the glory of the artilleryman's dreams seems askew, the incongruity of its theme and images with its setting suggests Whitman's most critical attack on the vision:

While my wife at my side lies slumbering, and the wars are over long,

And my head on the pillow rests at home, and the vacant midnight passes,

And through the stillness, through the dark, I hear, just hear, the breath of my infant,

There in the room as I wake from sleep this vision presses upon me. . . . (317)

Just as the mother's withdrawal into death in "Come up from the Fields Father" signifies the corruption of the family and, symbolically at least, the fruitful bounty of America by the war, the artilleryman's dream carries him away from the present, from peace, from wife and child. Being "worthy of the guns" becomes an obsession, separating him from the bonds of human affection which knit the social fabric of democracy in Whitman's political conception. The poem's opening lines testify to the veteran's return to a "normal" life. But his dream suggests, as M. Wynn Thomas observes, that "Whitman came to suspect that the qualities of men at war were not, after all, the stuff from which a new civilian society could be made." 5 The experience of war and its antidemocratic, anti-individual nature cannot be integrated into home life, but surreptitiously remains, strengthening those qualities within the individual which reject freedom and independence.

Unable and unwilling to exclude these forces of the modern and "en masse" from his poetic and political vision of America, Whitman invoked figures to counterbalance their anti-individual and antidemocratic tendencies. His most famous challenge to the war's dehumanizing power comes in his personal and poetic role as nurse and comforter of the wounded. The wound-dresser, the name taken from the Drum-Taps poem of that title and often used as a metaphor for Whitman's work in the field hospitals, is alienated from the forces which threaten the individual but does not rebel against them:

(Arous'd and angry, I'd thought to beat the alarum, and urge relentless war, But soon my fingers fail'd me, my face droop'd and I resign'd myself,

To sit by the wounded and soothe them, or silently watch the dead;). . . . (309)

Disillusioned with the drums of war, the speaker's "resignation" is not a capitulation to their terrible power but a subversive dedication to the individual fate the drums would overwhelm. Like the artilleryman and 
the "hard-prest" soldier, the wound-dresser speaks directly to the reader of his experiences. The wound-dresser's story, however, is distinguished by his attention to individual men and his steady, unblinking ability to see the horrors before him. There are no "crowds" of wounded in "The Wound-Dresser," no "forms" unperceived as men, although the number of men he treats is great:

To the long rows of cots up and down each side I return, To each and all one after another I draw near, not one do I miss. . . (310)

To preserve this respect for the sovereignty of the individual and to heal him, the dresser must look at each wound carefully and clearly. No sight is too ugly, nor smell too "offensive." To cleanse away the infection, the dresser must first face it. He sees what even the wounded soldier himself will not face:

From the stump of the arm, the amputated hand,

I undo the clotted lint, remove the slough, wash off the matter and blood, Back on his pillow the soldier bends with curv'd neck and side-falling head, His eyes are closed, his face is pale, he dares not look on the bloody stump, And has not yet look'd on it. (310-311)

As poet of the war, Whitman fulfills the same duties as the wounddresser. He is our witness to the horrors of war, facing them in order to heal the nation. The army hospitals were, for Whitman, the "marrow of the tragedy" ( $S D, 1: 117)$. There he fought the "real war," which meant not killing but saving lives, not the meeting of massive armies but of individual men in the face of chaos, suffering, and death.

"The Wound-Dresser" is framed as a recollection years after the war, when the speaker, now an old man, is asked to "be witness again" and tell "What stays with you latest and deepest" (309). His testimony, refusing battles and tales of heroic action as its subject, becomes another act of healing. His "remembering" is in opposition to the "dismembering" of wounded soldiers so characteristic of Civil War battles. He cannot reattach the amputated hand of the pale soldier he treats, but his ministrations and memories demonstrate that the wholeness of the individual is defined by that which "stays ... . latest and deepest"-an ability to love, the spiritual not the physical. The body politic, dismembered by secession, can also be healed only in this way. In "Over the Carnage Rose Prophetic a Voice," love is figured as a bond "stronger than hoops of iron":

(Were you looking to be held together by lawyers?

Or by an agreement on a paper? or by arms?

Nay, nor the world, nor any living thing, will so cohere.) (316) 
Only love can unite the body of the individual or of the nation.

The figure of the lover/comrade offers Whitman's most radical and positive challenge to the war's dehumanizing power. Although many critics have contended that Whitman's work in the hospitals allowed him to "sublimate" his homosexual desires into more socially acceptable relationships with the wounded, Jack Cady has argued that the intense bonding of men at war gave Whitman (and other gay writers before and after him) a motif which freed him to express the passionate attachment between men. ${ }^{6}$ But more significantly, Whitman's homosexual impulse, the intimacy of the connection he was able to feel and imagine between men, allowed him to salvage his democratic dream from the antidemocratic spectacle of modern war. Comrades who were lovers became bonded by more than arms. The two most intimate poems of passionate comradeship address the two questions Whitman had the most trouble reconciling in Drum-Taps. "Vigil Strange I Kept on the Field One Night" faces death and demonstrates that the most appropriate way to appreciate the cost of an individual life and to lay the dead to rest is as a lover. "As I Lay with My Head in Your Lap, Camerado" addresses the need for men bonded in love and affection to continue fighting against the anti-individual and anti-democratic forces in American society even after the war has ended.

"Vigil Strange I Kept on the Field One Night" is framed by the separation of two comrades by the terrible imperatives of war. Fighting side by side, one falls. His comrade can take time for only one look, "One touch of your hand to mine $\mathrm{O}$ boy, reach'd up as you lay on the ground," before he must move on with the battle (304). But unlike the soldier of "A March in the Ranks Hard-Prest," the speaker is finally "reliev'd" of his duties and returns to the side of his comrade. There he finds "in death so cold dear comrade, found your body son of responding kisses, (never again on earth responding,)." The speaker calls the dead soldier by turns "my son," "my comrade," "my soldier," and "boy," but the repetition late in the poem of "boy of responding kisses, (never again on earth responding,)" identifies him as lover.

In "Song of Myself" Whitman comes to a crisis when he envisions those who died in John Paul Jones' defeat of the British. He approaches despair-"Oh Christ-my fit is mastering me!"7 - and is only able to overcome it through an invocation of Christ's resurrection. The death of the comrade in "Vigil Strange," however, cannot be transcended through a figure of Christian rebirth. The loss of "responding kisses" is too intensely personal to be made good by invoking larger patterns of order. The speaker holds out the hope that they will be reunited, but it is based on the love they shared in life, not in any regenerative vision of a martyr's death. 
... (I could not save you, swift was your death,

I faithfully loved you and cared for you living, I think we shall surely meet again, ....( (p. 304)

The speaker's response to the loss of his lover/comrade is to keep vigil with the body through the night until dawn. Although vigils for the dead are common, the speaker's actions are not a response prescribed by tradition but a personal and spontaneous testament of love: ${ }^{8}$

Bared your face in the starlight, curious the scene, cool blew the moderate

night-wind,

Long there and then in vigil I stood, dimly around me the battle-field spreading,

Vigil wondrous and vigil sweet there in the fragrant silent night,

But not a tear fell, not even a long-drawn sigh, long, long I gazed,

Then on the earth partially reclining sat by your side leaning my chin in my

hands. . . . (304)

The speaker's posture recalls that of "Walt Whitman," loafing and leaning on the grass in "Song of Myself." Escaping here from the artificial strictures of war rather than the "Houses and rooms . . . full of perfumes," the speaker's casual and personal reaction is in its way as radical a departure from socially prescribed conventions as the poet's introduction, "hankering, gross, mystical, nude."

The speaker must walk away from the war, and all the subsuming forces it embodies, in order to keep his vigil of "silence, love, and death." He acts out of duty, but it is a strictly personal one, entailed by love with no ties to military code. He calls the dead soldier "my brave boy," although, as in "Come Up from the Fields Father," no mention is made of the cause in which he died or whether the battle was won or lost. His bravery is defined by the ultimate act of courage in Drum-Taps, facing death alone. The speaker imitates his lover's courage and refuses comfort from those forces which would place the death of the one against the needs of the many - the same forces which brought the men to war. Taps is not blown, no flag-draped coffin conceals the boy's identity. Instead the speaker sits alone with the body through the dark night. And then at dawn he ends his vigil:

Vigil for comrade swiftly slain, vigil I never forget, how as day brighten'd, I rose from the chill ground and folded my soldier well in his blanket, And buried him where he fell. (304-305)

The poem's move from the dark night to dawn figures the nation emerging from the war to face the price paid. The speaker's acceptance of the dead as his own to bury, in an intensely personal act of love and loss, eschews despair and resists the subsuming forces which diminish individuality. 
In "As I Lay With My Head in Your Lap, Camerado," Whitman invokes a scene of casual but passionate intimacy to confront the challenges to be faced at the war's end. The poem shares the isolated intimacy of "Vigil Strange," as the speaker "confesses" to his lover his determination to "confront peace, security, and all the settled laws, to unsettle them," (322). His resolution is born of his marginal status:

I am more resolute because all have denied me than I could ever have been had all accepted me,

I heed not and have never heeded either experience, cautions, majorities, nor ridicule. . . . (322)

A homosexual in the nineteenth century would undoubtedly meet with denial and ridicule; experience, caution, and the opinions of the majority would argue against confronting established institutions. But the speaker turns this denial into strength, as it empowers him to wage total, Satanic rebellion against the oppression he has met. The punishments and rewards, the "hell" and "heaven" of a society that has ostracized him cannot influence his actions. Yet the lover/rebel is not a party of one. His fight is for both the right to his own sense of individuality and the right to bond freely in love and affection with whom he chooses. As such, his stand embodies basic democratic principles and is not anti-social, but anti-institutional, offering a model of personal and political attachment which embraces all citizens of postwar America, male and female, homosexual and heterosexual.

The poem simultaneously marks the disbanding of the Union troops and heralds the battle Whitman would call for in Democratic Vistas, a literary revolution which would finally defeat the antidemocratic forces in American society. Although Whitman figures the conflict in militaristic imagery, the speaker's weapon is not the gun but words:

I know I am restless and make others so;

I know my words are weapons, full of danger, full of death;

(Indeed, I am myself the real soldier;

It is not he, there, with his bayonet, and not the red-striped artilleryman;) . . ${ }^{10}$

The parenthetical aside was deleted in the 1881 edition of Leaves of Grass, but it emphasizes the poem's conviction that the anti-democratic forces in American society could not ultimately be defeated by force of arms. In "Over the Carnage Rose Prophetic a Voice," Whitman proclaims "The dependence of Liberty shall be lovers,/ The continuance of Equality shall be comrades" (316). But the speaker of "As I Lay with My Head in Your Lap, Camerado" is less sanguine about the lovers' 
ability to redefine the social bonds on such libertarian and egalitarian models. The speaker's confession ultimately centers on his doubts about the success of his rebellion:

Dear camerado! I confess I have urged you onward with me, and still urge you, without the least idea what is our destination,

Or whether we shall be victorious, or utterly quell'd and defeated. (322)

The alienation of the homosexual lover is shared by Whitman the poet, whose Leaves were also denied and ridiculed by readers and critics of the day, just as the posture of the two lovers suggests a reader holding the book of poems. Whitman's words were always "restless," but the acknowledgment that his words were "weapons, full of danger, full of death" carried a double edge as the Civil War drew to a close. Not only endangering the fossilized power of social conservatism, his "word of the modern . . . a word en masse" found new definition in the carnage of battle. The first modern war had amply demonstrated that the mechanical, social, and political forces of modernity could be marshalled to destroy the power and life of the individual as easily as to protect them. Whitman knew, however, that there was no going back; he could not deny the fact or even the necessity of the war, although he was sickened and frightened by the forces it released.

The figure of the lover/comrade, like that of the wound-dresser, has the power to counter those forces because it was born itself of the war. In the face of death and events beyond their control, individuals reached out and forged bonds with one another, affirming their individuality and humanity through love. If the comrades of war could become lovers in peace they could represent the "spiritualizing" power Whitman warned was necessary to counter modern materialism, "or else our modern civilization, with all its improvements, is in vain, and we are on the road to a destiny, a status, equivalent, in its real world, to that of the fabled damned" (DV, 2:424). In "A March in the Ranks Hard-Prest, and the Road Unknown" Whitman saw that infernal road all too vividly. But "As I Lay with My Head in Your Lap, Camerado" offers the hope that the unknown road might yet yield victory to lovers dedicated to liberty and equality.

\section{University of California, Riverside}

\section{NOTES}

1 Daniel Aaron, The Unwritten War: American Writers and the Civil War (New York: Knopf, 1973). In his discussion of Melville's Battle-Pieces, Aaron writes, "The War may leave the 'Iron Dome' (symbol of the Capitol and the nation) 'stronger for stress and strain,' but the prophesy of an imperial United States flinging its 'huge shadow athwart the main' and establishing an iron dominion clashes with the Edenic hopes of the early 
republic" (80). Aaron goes on to discuss the significance of placing an ex-Confederate officer at the center of Clarel.

2 Walt Whitman, Leaves of Grass: The First (1855) Edition, ed. Malcolm Cowley (New York: Viking, 1961), 47.

3 Walt Whitman, Prose Works 1892, ed. Floyd Stovall (New York: New York University Press, 1964), 2 vols. All further references are taken from this edition and marked by volume and page number. Selections from Specimen Days and Democratic Vistas are marked $S D$ and $D V$, respectively.

4 From "As I Lay with My Head in Your Lap, Camerado," Leaves of Grass, Comprehensive Reader's Edition, ed. Sculley Bradley and Harold Blodgett (New York: Norton, 1973), 454. All further references are cited in the text by page number from this edition.

$5 \mathrm{M}$. Wynn Thomas, "Whitman and the American Identity Before and During the Civil War," Journal of American Studies 15 (1981), 90.

6 Joseph Cady, "Drum-Taps and Homosexual Literature" in Walt Whitman: Here and Now, ed. Joann P. Krieg (Westport, CT: Greenwood Press, 1985), 49-60. For readings of Whitman's sublimated homosexuality see Roger Asselineau, The Evolution of Walt Whitman (Cambridge: Harvard University Press, 1960), 172-174; Daniel Aaron, The Unwritten War (New York: Knopf, 1973), 65; Stephen A. Black, Whitman's fourney into Chaos (Princeton: Princeton University Press, 1975), 230.

7 Cowley, 67.

8 Denise Askin makes a similar point in "Retrievements Out of the Night: Prophetic and Private Voices in Whitman's Drum-Taps," American Transcendental Quarterly 51 (Summer 1981), 217.

9 Cowley, 43.

10 F. DeWolfe Miller, ed., Walt Whitman's Drum-Taps (1865) and Sequel to Drum-Taps (1865-1866): A Facsimile Reproduction (Gainesville, FL: Scholar's Facsimiles and Reprints, 1959), 19. 